\section{Arne Ljungqvist: the great fighter against doping}

\author{
Per Renström
}

Professor emeritus Arne Ljungqvist from Karolinska Institutet, Stockholm, who has served in various high positions in the IOC, International Association of Athletics Federations (IAAF), Swedish Sports Confederation, to mention some of them, has dedicated a great deal of his life to service in sports and sports medicine. Arne Ljungqvist has especially dedicated his career to the fight against doping and to the protection of the health of the athletes.

It is a great privilege for me to write this editorial as I have known and worked with Arne since the beginning of the 1970s. During the 1980s, I was a member of the Swedish Council of Sports Research under Arne's leadership and later his successor as President. Above all, I have had the privilege to work in the IOC Medical Commission since 1989, and from 2003-2012 under the Chairmanship of Arne. During these years we have worked closely together, and it has been a great journey to learn from Arne how to manage the many difficult and intriguing problems that follows the Olympic Games. Now, Arne is stepping down from the Chairmanship and leaving the IOC Medical Commission this year after years of distinguished service.

Correspondence to Professor Per Renström, Department of Molecular Medicine and Surgery, Centre for Sports Trauma Research, Karolinska Institutet,

Stockholm, Sweden; per.renstrom@telia.com
It all started over 60 years ago when Arne became a Swedish senior champion in high jump in 1951, jumping as high as $201 \mathrm{~cm}$. Arne was multi-talented and won also the Swedish junior championships in pole vault and javelin. He was one of the favourites for the Gold medal in the high jump competition in the Olympic Games in Helsinki 1952, but unfortunately could not compete because of an injury that he sustained during a medical student carnival in the autumn of 1951 when a group of us were jumping for the general public in the streets with numerous hard landings on asphalt. Arne had to end his jumping career as his injury could not be cured, and it was not until the 1960s that the diagnosis of patellar tendinopathy could be made.

Arne, however, continued his medical studies and soon became very successful. Arne was appointed professor at the Karolinska Institutet in 1972 because of his excellent medical research in the fields of renal and cardiovascular diseases and, later, oncology. He held several high professional positions such as Vice Dean of Medical Faculty, Karolinska Institutet, 1972-1977; Pro-Rector, Karolinska Institutet, 1977-1983; Chairperson, Department of Pathology and Cytology, Karolinska Hospital, 1983-1992; President, Swedish Council of Sports Research, 1980-1992; Dean Swedish School of Sport and Physical Education, 1992-1996; and President of the Swedish Cancer Society, 1992-2001. Interestingly enough, he took time to serve Chamberlain to His Majesty the King of Sweden, 1977-1986 and has since then been Lord in Waiting to His Majesty the King of Sweden.

In 1971, Arne returned to sport as he was elected to the Board of the Swedish Athletics Association, where in 1973 he became chairperson. In this time period, athletes used all kinds of medicines to enhance their bodies to achieve success. An anonymous survey among Sweden's best athletes indicated that nearly half of them were using anabolic steroids, which indeed was legal until 1975, when reliable tests had finally been developed to identify users. Arne realised that something had to be done to create a healthy and ethical environment in sports. In 1975, he became a member of the Swedish Sports Confederation and was part of the initiation of the Swedish Commission against doping in 1977 with its own doping rules by 1979 . During 19892001, Arne became the President of the Swedish Sports Confederation and in 1989 a member of the Swedish Olympic Committee.

Arne has had an outstanding international career, which started when, in 1976 he was elected to become a Council Member in IAAF and elected Vice President in IAAF in 1981. He served in this position until 1999 and became thereafter the Senior Vice President of IAAF until 2007 and Chairperson of the Medical Committee and Anti-Doping Commission. Since 1987 he has been a Member of the IOC Medical Commission and in 2003 he was appointed Chairperson of the Medical Commission of IOC. In 1994, Arne was elected Member of the IOC. When WADA was founded in 1999, Arne became the Member of WADA's Foundation Board 
and Chairperson of WADA's Health, Medical and Research Committee. Since 2003, Arne has been a Member of WADA's Executive Committee and since 2008 has been WADA's Vice President.

This means that Arne is sitting in important international positions in the fight against doping. Arne has really shown that he is equal to the task and has been the leading spokesperson in sport against doping. $\mathrm{He}$ is very qualified to hold this position. He is not only the ultimate diplomat but he is also very knowledgeable and skillful in his way of summarising even complex issues and problems. I discovered Arne's great ability in this aspect when I was sitting in the Swedish Council of Sports Research with Arne as a chairperson. Arne seldom gave any personal view on a specific problem or seldom took a direct stand, but when it came to summarise the discussions he would always tell them well, so he would make a brilliant summary and then the decision was easy to make. He has respect not only in the sporting world, but also in the media world.
Arne has been the front-line fighter against doping and his name is today one of the world's most respected within international sports. Arne's contributions in the fight against doping are second to none. He has been an athlete himself, which makes him understand the special language that is present in the athletic situation and also in the locker rooms. He can talk to an athlete in his/her own language and this is an important factor in order to gain the confidence of an athlete. Arne has furthermore had access to the athletic arenas, to the labs and to the boardrooms where the fight against doping has been going on. His position in the Boards of IAAF and the IOC has been unquestioned based on his knowledge, his intelligence and his diplomatic skills.

In his autobiography "Doping's Nemesis", Arne gives an unrivalled insider's view of the biggest dope scandals over the years, including the Ben Johnson and Balco affairs and the history of the Greek sprinters at the Athens Olympics in 2004. Arne's actions together with the Italian police during the Torino Olympics 2006 against the Austrian team are classic.
Doping seems to be steadily on the decline, and there is no doubt that Arne has played a key role in this successful work. Arne's legacy in the fight against doping is lasting.

Competing interests None.

Provenance and peer review Not commissioned; internally peer reviewed.

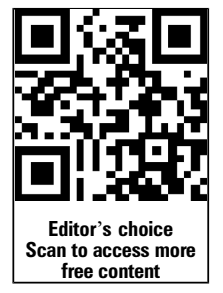

To cite Renström P. Br J Sports Med 2014;48:2-3.

Accepted 26 August 2013

Published Online First 24 September 2013

Br J Sports Med 2014;48:2-3.

doi:10.1136/bjsports-2013-093029 